\title{
The Theory of Factual Trust
}

\author{
Li Shu \\ School of Civil and Commercial \\ China University of Political and Law(CUPL) \\ Haidian, Beijing \\ 2508008308@qq.com
}

\begin{abstract}
In 1998, the court of Guangdong Province has recognized the factual trust. This is the first time and the only time that the court identified the factual trust. So this paper starts from the judge of the case, then analyzes clearly that what is the trust factual and the aspects of trust factual, and how to establish the trust factual.
\end{abstract}

Keywords-trust; factual trust; formulate trust; constitutive requirements;

\section{THE ANALYSIS OF CASE}

There are three types of trademarks: TMT, TMC and SMT. The three trademarkes are designed by the company of dongming and are used actually by that company. After the dissolution of that company, three trademarks have been bought by TMT. Besides, the three trademark have been used by TMT, but the predecessor company needs to use in the mainland of dongming. These trademarks continue to play its proper role in the TMT Company, and it files for termination with the light industrial products corporation that is commissioned. The request of returning three trademarks shall be supported by industrial products of the company. From then on, the first court considered that the two parties have established a legal relationship, and that relation is the entrusted relationship. Because the entrusted relationship can be terminated at any time according to the provisions of article 410 of the contract law.

Basic recognition has been identified by the court and the court identified the factual trust. According to the "general principles of the civil law", it thinks that the original and relevant provisions of the verdict that returns the three trademarks to the TMT Company is right, but it don't think that the relationship of entrust and the factual trust relationship between the two parties. The company of the light industrial products is related to the trademark holder, and the holder of the TMT Company is essentially related to trademarks. The light industrial products company requests to buckle under the condition of TMT companies when it exports products. The TMT Company with the identity of the client requests to return the three trademarks because the company has adequate facts. The original review identifies that it is as a principal-agent relationship, and the fact that the trademark is registered and is managed is not considered.

First of all, there are some questions about the decision of the first court:

1. Some questions that are about to the establishment of the commissioned relationship of the two parties. Article 163 of the new General Principles of Civil Law stipulates that "the entrusting agent shall exercise the proxy right in accordance with the entrust of the agent." Article 162 stipulates: "The agent shall, within the authority of the agent, carry out the civil legal acts in the name of the agent, and the agent shall bear the civil liability for the agent's act of the agent." From the definition of the principal, the trustee needs to act in the name of the client and in the name of the law, and in this case, the light industrial products company is the registrant of the three trademark in mainland China, it has the absolute management and manageable rights. Far beyond the legal status, the trustee is the subject in the entrusted relationship.

2.Some questions that are about to the termination of the principal-trust relationship. In the first court, the judge uses the entity legal basis of "general principles of the civil law",the article 4 , the article 5 of the paragraph 1 , the article 65 and the article 69 of the item, but the general principles of the civil law "the two articles of 4 and 5 belong to the content of the basic principles in the general case and cannot serve as a referee's legal basis, besides the article 65 is about to the establishment of the principal-agent problem, the article 69 is about to the death of the principal-agent problem. Any other legal basis used by the referee shall not be appropriate except for the article 69 of paragraph 2, which is called by the agent or the agent resigning the trust and the commission is removed.

Secondly, there are some questions about the court's ruling:

1. Some questions that are about to the factual trust. The socalled factual trust, as the name implies, is not a formal trust. From the article 8 of the trust law, it can be seen that the trust act is a kind of behavior and needs to be written in writing, so the factual trust must be signed in a trust contract. Contract methodology is from the formalism to the essence of socialism.[1] When the nature of the judging is the contract, the content of the contract is the basis of judgment. If the content of the contract points to the trust relationship, the trust relationship shall be determined directly between the parties. In fact, the judging from the court decision, even if there is a contractual relationship between the parties, there is no content of the trust. Then, without any factual basis, it is necessary to explore further whether there is actually a theoretical selfconsistency between the parties.

2. About the validity of the factual trust. According to the article 2 of the trust law, the trust referring to the client is based on the trust of the trustee. The property is entrusted to the agent by the will of the trustee according to the client in its own name. For the benefit or a particular purpose, there is the manage or 
the dispose for the behavior. The basic elements of the trust can be seen from this definition: the trust subject, the trust property, the trust behavior and the purpose of the trust. Trust was established and validated that must satisfy these four elements at the same time. In fact, the trust may satisfy the relevant elements of trust in certain aspects, but this does not mean that the factual trust can play a role of trust in law, because the state is also required the specific analysis. According to the provisions of the article 10 of the trust law, the trust that is established with specific property also needs to deal with relevant formalities. And if lack of these procedures, it is bound to cause a similar "property law" which is stipulated in the article 14 of the real right that is changing the effect and the result in the procedure of application.

In conclusion, the actual trust in the legal relationship between the parties is very controversial in itself. The court, in addition to the use of "actually trust" in the case of the interpretation method, is no longer applied in other case, and the later has a local court according to the principle of trust law per provide relief to the litigants, but is not recognized by most scholars of theoretical and practical circles. How to view the existence of the factual trust and how to decompose it according to the composition of the trust are important. In fact, the establishment of the trust is the important content of the necessity of the factual trust per exist in the future.

\section{The NATURE OF FACTUAL TRUST}

Factual trust is not based on the intention of the parties and the establishment of trust relationship. It is unfair between the parties. The court was based on the principle of equitable justice, and forced to set up a trust relationship in any way. In fact, the trust is based essentially the court's remedy of fairness and justice, and the remedy is created by the trust law. I'm afraid that if set up the trust between the parties, the problem is that one of the parties for the subject has the matter of property rights, in comparison, the other party have the rights and interests of a significant loss, in order to safeguard the legitimate rights and interests of the other party, setting up the trust relationship is important between the parties. One is artificial as the trustee of property rights, while the other is artificial for the trust and at the same time curbs the build-up of the beneficiary. The trust of the bootstrap requires the principal that may revoke the trust relationship for property rights and return to the subject.[2]

Negotiable system exists in the civil law system in our country and is the system of unjust enrichment. The two systems is to adjust the unfair property relationship, and some scholars think that since our country has the trust law, it should be admitted that the artificial trust (trust). In fact, acknowledging the role of the trust concept in the civil relief system is so as to establish a perfect system of trust law theory. But what we need to understand is that if the existing legal system can solve problems, there is no need to create a new system. Can the management system and the improper benefit system satisfy the dispute demand of the parties? Negotiable system stresses the parties in the case that are unknown or have the contractual legal relationship; one party is to manage for the benefit of other parties transaction behavior. But the disputes between the parties in general are a trade relationship, and in order to seek their biggest interests at the expense of the other party, the parties of the holder of the property need to keep its property rights, therefore it does not meet the requirements of the composition of negotiable system.[3]

\section{Constitutive ReQuirements 0F FACtual Trust}

\section{A. Subject of Trust}

In general, the trustor of the trust is the provider of the trust property, the founder of the trust and the originator of the trust structure. Factual trust is a relationship of trust between the parties. The article 19 of the trust law states: "According to law the trustor shall be a natural person, a legal person or other organization established with complete civil capacity." This is according to the regulation of our country, in addition to the special laws and the regulations on the requirements of the principal. With any disciplinary action, specific property rights having capacity for civil conduct of natural person, legal person or other organization can become the principal.

The trustee is the sole owner of the trust property and has the absolute and exclusive setting of the trust property. From the paragraph 3 of article 8 of the trust law: "the trust is established by way of the trust contract and trust contract is signed, then the trust is established. A trust established in other written forms shall, when the trustee promises to accept the trust set up", become the trustee of the trust that the subject needs to get its promise. The establishment of the trust by means of contract is the result of the autonomy of the parties (principal, the trustee), and the existence of the fact is that the trustee can be presumed to be granted by the trustee. Trust is established when the trustee promises to accept the beginning with the main body of the commitment as the trustee and the trust was set up. If the trustee doesn't promise, then the trust is not established. It needs to retain the trustee separately and the trustee promises the trust.

In fact, the beneficiary of the trust is also made by the court and is for balance the legitimate rights and interests of the parties. As long as the trustee has the proper management and operation of the trust, the trustee not only the beneficiary has right to interfere in the process of management behavior, but also has the benefits of the trust.

\section{B. The trust property}

As a property management law, trust property is independent of the trustor, trustee and beneficiary, which is the necessary factor in the trust structure. The uniqueness in the trust system of its own responsibility has the isolation effect and the responsibility of the legal person system produce isolation that is different from the emphasis on faith obligations of the trustee trust. And this is different from a legal person's duty of loyalty and diligence obligations such as directors or supervisors. What need to do is to shall assume unlimited liability and to pay more attention to the trustee and its inherent property.

The article 7 of the trust law states: "To establish a trust, a certain trust property must be established and the property of the trust must be lawfully owned by the trustor." So by the time set up the trust, the trust property of the original need to have certainty, legitimacy, disposable and inherent negotiability 
(marketability) through the brand value evaluation. It can become the part of the enterprise capital contribution as intangible assets. As to the problem of disposable sex, the trust law has stipulated in article 14 "Properties are forbidden to circulate by laws and administrative rules and regulations shall not be used as trust property. The laws and administrative regulations limit the circulation of property, in accordance with the approved by the competent department concerned, it can be used as trust property."

\section{Trust behavior}

The trust law stipulates in article 8: "The trust is established, and the written form shall be adopted. Written form includes trust contracts, wills or other written documents as provided by laws, administrative rules and regulations. A trust contract is formed to establish a trust, when there is a trust contract signed, then the trust was established. A trust can is established in other written forms when the trustee promises to accept the trust was set up." This article contains three aspects of the analysis.

In our country, the adoption of the doctrine of the need for trust is the express of trust, which is more obvious in the article 9 of the trust law. Belong to the implied in fact to accept the trust of the artificial trust, and the court is based on the idea of fairness and justice in the process. The referee assumes that there is a relationship of trust between the parties for balance the interests between the parties. Since it is a relationship of trust that belongs to the court, there will no be written form of trust. The explicit requirement for setting up a trust is a requirement of our country, and there is no general writing requirement in the Japan trust law. In order to promote the establishment of the trust relationship, the legal relationship should be interpreted as the trust behavior in the civil field. Therefore, although the parties did not express the meaning of "setting up the trust", the trust is established.

Trust law allows the means of contract, will and law and administrative rules and regulations. A trust is established in the form of a contract, the principal and the trustee are the parties to the trust contract. A trust established in the form of a will is an expression of the unilateral meaning of an heir (client), and the trust is established if the trustee promises. It is clear that trust is not a trust established in the form of contract or will, even if there is a contract between the parties. Whether is in writing or not, the actual trust will be incorporated into other forms of law and administrative regulations? It is generally believed that this provision is the legal space for the development of the declaration of trust. Can it also provide a legal basis for the practice of the implied trust? I think not. The first rule of civil law in Taiwan is that: "Civil law is not prescribed by law. This is a more general rule in civil law of the civil law system, and China, as the successor to the legal theory of mainland law system, and the legal theory has been widely used in judicial practice. In fact, the trust is based on the trust law, and the trust is established according to law that can also be used as a form of establishment. Of course, these explanations seem too far-fetched, and easily fall in logic in the loop body, but the law loopholes is existing actuality and the establishment of the unique way is to provide legal basis.

"When a trust is established in the form of a trust contract, the trust is established when the trust contract is signed. Other written forms shall be established for the trust, and the trust shall be established when the trustee promises the trust." The contract law is established and the basic principle of the formation of the contract is the notability. The result of the selfgovernment of a trust is formed in the form of contract and shall be established as long as it is not invalid, revocable and effective in the contract law. If the trust is established by the will and a will is as unilateral ACTS, the trustee don't agree to assume the obligations, then it subjects to the law as a trustee. One specified in the property as the trust property trust is not established, but this does not mean that the will of the trust cannot be established and take effect, which can be selected by the beneficiary and the court considers the interests of all parties in the trustee that shall be under the premise selected and set up a trust relationship. In fact, the trust is based on the trust theory and the trust relationship between the parties is to be formed. It is the operation of the law and provides remedy for the wrong behavior or prevents the unjust enrichment. The trust agreement is not set up between the parties, therefore the establishment of the trust, in fact needs to break through the content of the parties and the establishment is self-evident. For the parties, it is as a legal means of relief, but some people think that it is "a ready-made tool" of modern social development property.

The trust law of the article 10 stipulates: "To establish a trust, according to the trust property law, the relevant laws and administrative rules and regulations, it shall deal with the formalities that register trust in accordance with the law. Did not handle the trust registration and in accordance with the provisions of the preceding paragraph, it shall fill formalities that register. If not fill the trust, it does not produce effectiveness." Concerning the public display of trust, registration of entry into force, registration of antagonism in continental law and the registration of entry into force are adopted in China. Some scholars believe that registration is more advantageous because it provides more choice space for the parties, and trusts as a kind of property arrangement, is more than other people. Forcing the parties to register increases the cost of setting up the trust, reduces the efficiency of the system utilization, and violates the will and judgment of the parties. The author thinks that, in the property law of our country, the real estate registration principle was adopted in the real right change and uses the movable property against principle. The key lies in the change of real right, so the complete real right changing registration will take effect and must be used for the chattel. Using registration counter in addition to transaction security and the protection of the third person also emphasize the choice and freedom of contract by the parties.[4]

In fact, the trust has no registration link, but the court thought that the client established the trust relationship. "Property law" of the article 28 states: Because of the legal document, the arbitration has the commission of the people court or the people government of a decision, etc.. Which lead to the real right establishment, alteration, transfer or wiped out, and the legal document or a people's government shall come into effect upon the effectiveness of a decision, etc." Which emphasizes that the court judge must lead to the real right, the establishment, change, transfer or termination in the trust legal 
relationship, so it in the property law provisions shall be applicable. According to the theory of "double consortium", the trust property becomes a special group, and this special group of property rights does not belong to anyone party of the trustor, trustee and beneficiary, not the so-called "no advocate content", but property rights that belongs to a kind of flexible structure, and needs to special treatment.

Therefore, the judgment of the people's court results in the change of the property right of the trust property, which is effective when the legal instrument takes effect. But even if the parties are actually established in trust, there is no registration for the third person. In addition, according to the stipulations of article 31 of the property law: "according to the provisions of the article from 28 to 30 , the real right of realty is enjoyed, any disposal thereof, is required to be registered in accordance with the law. It has not been registered, not the real effectiveness." Generally speaking, the court determines that the reason of the actual trust relationship is to restore the rights and the obligations of the parties.[5]

\section{The purposes of the trust}

Article 6 of the trust law states: "The establishment of a trust must have a legitimate trust purpose." The legality of the purpose of the trust is manifested in the non-violation of the mandatory provisions of laws and administrative regulations, and does not violate the principles of civil law of public order and good customs. In the case of the existence of the above situation, specific problems need to be analyzed, and the legitimacy of the case is determined. There is always a belief that trust is the product of unreasonable laws and laws, and the mandatory provisions of laws and administrative regulations refer to enforceable rules rather than administrative rules. And ineffective violation of mandatory rules will often harm the national interests and social interests. The situation can be concluded that the validity of juristic act, and may need to be given administrative penalties and which is another matter.

\section{The Legal EFfeCt OF THE TRUST}

In fact, the trust is a kind of equitable remedy that the people's court provides the parties through judicial operation. A trust is not a party's freedom to set an express trust that is created by the court. In fact, it has the attribute of judicial creation, because it is not certain in itself, so the legislation cannot establish the standard, and it is inevitable that the judicial discretion will be required. According to the legal relationship, the parties have objectively the trust relationship. You will need to undertake concrete analysis according to the components of the trust, if it is identified as the trust, the trust relationship exists between the parties under the premise of legal relationship adjustment.

Article 55 of the trust law: "In accordance with the provisions of the preceding article, the trust property, after the confirmation of the ownership transferred the trust property rights belong to the process of trust as a survival. Only if the trust terminates, the trust relationship between the parties will cease to exist. Although this is composed of legal fiction, but the court's artificial trust principle is the same, if you want to achieve the purpose similarly. The court decided that the parties set up the trust relationship and the trust is also belongs to the trust for meet the constitutive requirements of the trust, which is based on the general rules of trust law. The express of trust is created and the trust has the same legal effect.[6]

\section{CONCLUSION}

The trust was created in the late middle ages and the main purpose of the trust was to circumvent the strict feudal legal system, which was relative to the express trust. In fact, the trust is established in order to resolve the dispute of the parties, which is based on the principle of fairness and justice in equity law. This conflicts with procedure of private law attribute, but in order to balance the interests, using the principle of trust law implied the existence of legal relationship is not in violation of the provisions of the laws and administrative regulations of mandatory, which is not from the civil law principle of public order and good customs should identify the existence of its legitimacy. The existence of trust relationship meets the constitutive requirements of trust. To express the related provisions of the trust to the left, some ways should be able to use the basic principle of self-consistent. Only in this way, the legal effect of the trust can be generated after the relationship between the parties. The country's attitude to the factual trust is rather vague, and the supreme people's court has not applied any more than the "factual trust" in this case. In the current procedure of mandatory rules, any laws and regulations have the trend of change and the court to use traditional remedy cannot provide adequate relief. The court uses artificial theory of trust, in fact, for explain the procedure. In order to perfect the civil relief system, the civil liability theory is an important part of the procedure of promoting the development of the civil law.

\section{REFERENCE}

[1] Sun Liangguo, from the formalism to the essence of socialism, the evolution of modern contract law methodology, carrying the BBS of law 5, 2007.

[2] Sen v. Headley [1991] Ch. 425 at 440 (Nourse L.J.)

[3] J.E. Penner, The Law of Trusts, fourth edition, Oxford University Press, $2005, \mathrm{p} 19$.

[4] Edward C. Halbach, Jr, Trust, Gilbert Law Summaries, Thomas/West, 2008, p283.

[5] Carl Zeiss Stiftung v. Herbert Smith \& Co, [1969] 2 Ch. 276 at 300, per Edmund Davies LJ. 